\title{
PENGARUH JUMLAH SEGMEN OPERASI DAN UKURAN PERUSAHAAN TERHADAP KETEPATAN WAKTU PELAPORAN LAPORAN KEUANGAN DENGAN REPUTASI KAP SEBAGAI VARIABEL MODERASI
}

\author{
Astuti Yuli Setyani, Eka Adhi Wibawa \\ Prodi Akuntansi, Fakultas Bisnis Universitas Kristen Duta Wacana \\ Email korespondensi: astutiys@staff.ukdw.ac.id
}

\begin{abstract}
ABSTRAK
Informasi yang terkandung dalam laporan keuangan harus relevan untuk memenuhi kebutuhan pengguna dalam proses pengambilan keputusan. Tuntutan akan kepatuhan terhadap ketepatan waktu pelaporan dalam menyampaikan laporan keuangan perusahaan publik di Indonesia telah diatur dalam Keputusan Ketua Badan Pengawas Pasar Modal Nomor KEP-346/BL/2011 tentang Penyampaian Laporan Keuangan Berkala Emiten atau Perusahaan Publik. Dalam lampirannya, yaitu Peraturan Bapepam Nomor X.K.2, menyebutkan bahwa laporan keuangan tahunan harus disertai dengan laporan akuntan dengan pendapat yang lazim dan disampaikan kepada Bapepam selambat-lambatnya pada akhir bulan ketiga (90 hari) setelah tanggal laporan keuangan tahunan. Penelitian ini bertujuan untuk menguji faktor-faktor yang mempengaruhi ketepatan waktu pelaporan laporan keuangan. Faktor - faktor yang diuji dalam penelitian ini adalah jumlah segmen operasi, ukuran perusahaan dan reputasi KAP sebagai variabel moderasi. Data yang digunakan yaitu data sekunder perusahaan LQ45 yang terdaftar di BEI tahun 2015 - 2019. Analisis data yang digunakan yaitu menggunakan Logistic Regression Analysis pada tingkat signifikansi 5\%. Diperoleh hasil bahwa jumlah segmen operasi dan ukuran perusahaan tidak mempengaruhi ketepatan waktu pelaporan laporan keuangan perusahaan. Sementara itu, reputasi KAP tidak memoderasi pengaruh jumlah segemen operasi dan ukuran perusahaan terhadap ketepatan waktu pelaporan laporan keuangan perusahaan.
\end{abstract}

Kata kunci: segmen operasi, ukuran perusahaan, ketepatan waktu, reputasi KAP

\begin{abstract}
The information contained in the financial statements must be relevant to meet the needs of users in the decision making process. The demand for compliance with the timeliness of reporting in submitting financial reports of public companies in Indonesia has been regulated in the Decree of the Chairman of the Capital Market Supervisory Agency Number KEP-346 / BL/2011 concerning Submission of Periodic Financial Reports of Issuers or Public Companies. In its attachment, Bapepam Regulation Number X.K.2, states that the annual financial report must be accompanied by an accountant's report with the usual opinion and submitted to Bapepam no later than the end of the third month (90 days) after the date of the annual financial report. This study aims to examine the factors that affect the timeliness of reporting financial statements. The factors tested in this study were the number of operating segments, company size and KAP reputation as moderating variables. The data used are secondary data from LQ45 companies listed on the IDX in 2015 - 2019. Analysis of the data used is Logistic Regression Analysis at a significance level of 5\%. The results show that the number of operating segments and company size do not affect the timeliness of reporting the company's financial statements. Meanwhile, the reputation of KAP does not moderate the effect of the number of operating segments and company size on the timeliness of reporting the company's financial statements. Keywords: operating segments, company size, timeliness, reputation of KAP
\end{abstract}




\section{PENDAHULUAN}

Salah satu sumber informasi penting dalam bisnis investasi di pasar modal adalah laporan keuangan yang disediakan setiap perusahaan yang go public. Kerangka Dasar Penyusunan dan Penyajian Laporan Keuangan (KDPPLK) tahun 2015 menyatakan bahwa tujuan laporan keuangan adalah untuk menyediakan informasi yang bermanfaat bagi sejumlah besar pengguna dalam pengambilan keputusan ekonomik yang menyangkut posisi keuangan, kinerja, serta posisi keuangan suatu entitas. Bapepam telah mengeluarkan peraturan Keputusan Ketua Badan Pengawas Pasar Modal Nomor KEP-346/BL/2011 tentang Penyampaian Laporan Keuangan Berkala Emiten atau Perusahaan Publik. Dalam lampirannya, yaitu Peraturan Bapepam Nomor X.K.2, menyebutkan bahwa laporan keuangan tahunan harus disertai dengan laporan akuntan dengan pendapat yang lazim dan disampaikan kepada Bapepam selambat-lambatnya pada akhir bulan ketiga (90 hari) setelah tanggal laporan keuangan tahunan.

Dalam penelitian sebelumnya oleh Ariyani dan Budiartha tahun 2014 menyatakan bahwa variabel kompleksitas operasi perusahaan berpengaruh signifikan terhadap audit report lag. Perusahaan yang memiliki unit operasi (cabang) lebih banyak akan memerlukan waktu pelaporan yang lebih lama bagi auditor untuk melakukan pekerjaan auditnya. Salah satu bentuk kompleksitas dari operasi perusahaan adalah segmen usaha, karena terdapat banyak jumlah unit operasi serta deversifikasi produk. Semakin banyak segmen usaha yang dimiliki perusahaan, maka waktu pelaporan yang digunakan auditor dalam melakukan audit semakin lama untuk memeriksa setiap segmen bisnis perusahaan. Selain kompleksitas operasi perusahaan, ukuran perusahaan juga diduga mempengaruhi ketepatan waktu pelaporan laporan keuangan. Ukuran perusahaan merupakan skala yang digunakan untuk mengukur besaran total aktiva pada akhir tahun. Pada penelitian ini, penulis menggunakan total aktiva untuk menentukan ukuran perusahaan. Semakin besar ukuran perusahaan maka waktu pelaporan yang diperlukan untuk mengaudit laporan keuangan cukup lama. Pada penelitian ini akan dilakukan pengujian kembali jumlah segmen operasi perusahaan dan ukuran perusahaan, karena jumlah segmen dan ukuran perusahaan perusahaan merupakan faktor yang berasal dari perusahaan yang dapat mempengaruhi proses pelaporan laporan keuangan. Hal ini menunjukan adanya faktor situasional lain yang diduga dapat merekonsiliasi temuan tersebut yaitu reputasi KAP. Reputasi KAP yang baik akan bekerja lebih profesional untuk mengatasi permasalahan dalam proses pengauditannya. Indikator reputasi KAP tersebut dapat dinilai dengan penggunaan jasa KAP yang berafiliasi dengan Big Four atau bukan Big Four. Penelitian ini menggunakan reputasi KAP karena dianggap mampu memperkuat pengaruh jumlah segmen operasi dan ukuran perusahaan terhadap ketepatan waktu pelaporan laporan keuangan.

\section{KAJIAN LITERATUR}

\section{Teori Keagenan}

Teori keagenan merupakan konsep yang menjelaskan hubungan kontraktual antara principals dan agents. Pemilik atau prinsipal adalah pihak yang melakukan evaluasi terhadap informasi dan agen adalah sebagai pihak yang menjalankan kegiatan manajemen dan mengambil keputusan (Jensen dan Meckling, 2005). Dalam penelitian ini, agen merupakan entitas sedangkan principal merupakan pengguna laporan keuangan atau investor.

\section{Teori Kepatuhan}

Dalam Undang-Undang No. 8 Tahun 1995 tentang Pasar Modal, telah diatur mengenai tuntutan akan kepatuhan terhadap ketepatan waktu pelaporan dalam penyampaian laporan keuangan tahunan perusahaan publik di Indonesia, dan selanjutnya diatur dalam Peraturan Bapepam Nomor X.K.2, Lampiran Keputusan Ketua Bapepam Nomor: KEP346/BL/2011 tentang Kewajiban Penyampaian Laporan Keuangan Berkala Emiten atau Perusahaan Publik. Peraturan-peraturan tersebut secara hukum mengisyaratkan adanya kepatuhan setiap perilaku individu maupun organisasi (perusahaan publik) yang terlibat di pasar modal Indonesia untuk menyampaikan laporan keuangan tahunan perusahaan secara tepat waktu kepada Bapepam. Hal tersebut sesuai dengan teori kepatuhan (compliance theory). 


\section{Laporan Keuangan}

Dalam Standar Akuntansi Keuangan (IAI, 2015) tujuan laporan keuangan adalah untuk menyediakan informasi yang bermanfaat bagi sejumlah besar pengguna dalam pengambilan keputusan ekonomik yang menyangkut posisi keuangan, kinerja, serta posisi keuangan suatu entitas. Dalam laporan keuangan menunjukan pertanggungjawaban manajemen atas sumber daya yang dipercayakan di perusahaan.

\section{Ketepatan Waktu Pelaporan Laporan Keuangan}

Bapepam kemudian memperketat peraturan dengan dikeluarkannya Keputusan Ketua Badan Pengawas Pasar Modal Nomor: KEP-346/BL/2011 tentang Penyampaian Laporan Keuangan BerkalaEmitenatau Perusahaan Publik. Dalam lampirannya, yaitu Peraturan Bapepam Nomor X.K.2, menyebutkan bahwa laporan keuangan tahunan harus disertai dengan laporan akuntan dengan pendapat yang lazim dan disampaikan kepada Bapepam selambat-lambatnya pada akhir bulan ketiga (90 hari) setelah tanggal laporan keuangan tahunan.

\section{Segmen Operasi Perusahaan}

Menurut IAI PSAK 5 tahun 2015, Segmen Operasi diartikan sebagai berikut :

"Segmen operasi adalah suatu komponen dari entitas:

a) Yang terlibat dalam aktivitas bisnis yang mana memperoleh pendapatan dan menimbulkan beban (termasuk pendapatan dan beban terkait dengan transaksi dengan komponen lain dari entitas yang sama),

b) Hasil operasinya dikaji ulang secara regular oleh pengambil keputusan operasional untuk membuat keputusan tentang sumber daya yang dialokasikan pada segmen tersebut dan menilai kinerjanya, dan

c) Tersedia informasi keuangan yang dipisahkan.

Segmen operasi dapat terlibat dalam aktivitas bisnis yang belum menghasilkan pendapatan sebagai contoh operasi permulaan dapat menjadi segmen operasi sebelum memperoleh pendapatan."

\section{Ukuran Perusahaan}

Ukuran Perusahaan dapat dinilai dari besar kecilnya aset yang dimiliki perusahaan. Berdasarkan Undang-undang RI No. 20 tahun 2008 tentang Usaha Mikro, Kecil, dan Menengah, menyatakan adanya pembagian skala atau kriteria usaha. Ukuran Perusahaan dapat dilihat dari jumlah aset yang dimiliki suatu perusahaan.

\section{Reputasi Kantor Akuntan Publik (KAP)}

Laporan keuangan harus dapat disajikan dengan akurat dan terpercaya. Oleh karena itu, perusahaan kemudian menggunakan jasa kantor akuntan publik (KAP) untuk melaksanakan pekerjaan audit terhadap laporan keuangan perusahaan. Di dunia, KAP yang memiliki reputasi yang baik adalah KAP yang berafiliasi dengan KAP besar yang berlaku universal yang dikenal dengan KAP Big4 ( Four Worldwide Accounting Firm).

Afiliasi KAP Big 4 di Indonesia adalah sebagai berikut :

1. KAP Price Water Coopers (PWC), yang bekerjasama dengan KAP Tanudiredja, Wibisana \& Rekan.

2. KAP Klynveld Peat Marwick Goerdeler (KPMG), yang berkerjasama dengan KAP Siddharta dan Widjaja

3. KAP Ernst and Young, yang berkerjasama dengan KAP Purwantono, Sungkoro, dan Sudja

4. KAP Deloitte Touche Thomatsu, yang berkerjasama dengan KAP Osman Bing Satrio dan rekan.

\section{PENGEMBANGAN HIPOTESIS}

Pengaruh jumlah segmen operasi terhadap
ketepatan waktu pelaporan laporan
keuangan.
Hal yang mendasari hubungan segmen operasi terhadap ketepatan waktu pelaporan laporan keuangan adalah semakin banyak segmen operasi yang dimiliki perusahaan, maka waktu yang digunakan auditor dalam melakukan audit semakin lama untuk memeriksa setiap segmen bisnis perusahaan dan menyelesaikan laporan auditnya sehingga ketepatan waktu pelaporan laporan keuangan menjadi menurun. Jumlah segmen operasi 
dapat dilihat dari total segmen yang dimiliki perusahaan.

Hipotesis 1. Pengaruh jumlah segmen operasi terhadap ketepatan waktu pelaporan laporan keuangan.

\section{Pengaruh ukuran perusahaan terhadap ketepatan waktu pelaporan laporan keuangan}

Hal yang mendasari hubungan ukuran perusahaan terhadap ketepatan waktu pelaporan laporan keuangan adalah semakin besar ukuran perusahaan, maka waktu yang digunakan auditor dalam melakukan audit semakin lama untuk memeriksa setiap aset perusahaan dan menyelesaikan laporan auditnya sehingga ketepatan waktu pelaporan laporan keuangan menjadi menurun.

Hipotesis 2. Pengaruh ukuran perusahaan terhadap ketepatan waktu pelaporan laporan keuangan

\section{Pengaruh jumlah segmen operasi terhadap ketepatan waktu pelaporan laporan keuangan dengan reputasi KAP sebagai variabel moderasi}

Dengan demikian, KAP yang berafiliasi dengan Big 4 apabila semakin banyak jumlah segmen operasi perusahaan maka akan meningkatkan ketepatan waktu pelaporan laporan keuangan. Reputasi KAP diduga mampu memperkuat pengaruh jumlah segmen operasi perusahaan terhadap ketepatan waktu pelaporan laporan keuangan. KAP yang bereputasi baik akan bekerja lebih profesional untuk mengatasi permasalahan dalam proses pengauditannya

Hipotesis 3. Jumlah segmen operasi terhadap ketepatan waktu pelaporan laporan keuangan dengan reputasi KAP sebagai variabel moderasi

\section{Pengaruh ukuran perusahaan terhadap ketepatan waktu pelaporan laporan keuangan dengan reputasi KAP sebagai variabel moderasi}

Dengan demikian, KAP yang berafiliasi dengan Big 4 apabila semakin besar ukuran perusahaan maka akan meningkatkan ketepatan waktu pelaporan laporan keuangan. Reputasi KAP diduga mampu memperkuat pengaruh ukuran perusahaan terhadap ketepatan waktu pelaporan laporan keuangan. KAP yang bereputasi baik akan bekerja lebih profesional untuk mengatasi permasalahan dalam proses pengauditannya

Hipotesis 4. Pengaruh ukuran perusahaan terhadap ketepatan waktu pelaporan laporan keuangan dengan reputasi KAP sebagai variabel moderasi.

\section{METODE PENELITIAN}

\section{Prosedur Pengumpulan Data.}

Dalam penelitian, penulis menggunakan data sekunder, yaitu laporan keuangan perusahaan LQ45 yang sudah diaudit dan telah dipublikasikan pada tahun 2015 - 2019 berturut-turut. Data ini diperoleh dari Laporan Tahunan perusahaan LQ45, Undang-undang Bappepam, dan publikasi-publikasi lainnya.

\section{Definisi Variabel dan Pengukurannya \\ Variabel Dependen adalah Ketepatan} waktu. Ketepatan waktu diukur dengan menggunakan dummy 0 dan 1 . Dummy 1 merupakan perusahaan yang mengeluarkan laporan keuangan yang telah diaudit sebelum 90 hari (31 Maret) dari akhir tahun tutup buku (31 desember). Sebaliknya, dummy 0 merupakan perusahaan yang mengeluarkan laporan keuangan yang telah diaudit setelah 90 hari (31 Maret) dari akhir tahun tutup buku (31 desember).

Variabel Independen terdiri dari Variabel segmen operasi dan Ukuran Perusahaan. Variabel segmen operasi diukur menggunakan jumlah segmen operasi yang dimiliki oleh suatu perusahaan. Sedangkan Ukuran Perusahaan diukur menggunakan LN total aset perusahaan.

Variabel Moderasi adalah Reputasi KAP. Reputasi KAP dalam penelitian ini diukur dengan menggunakann kelompok auditor Big Four dan Non Big Four. Reputasi KAP diukur dengan menggunakan dummy, yaitu 1 jika KAP berafiliasi dengan KAP Big Four dan 0 jika KAP tidak berafiliasi dengan KAP Big Four. 


\section{Desain Penelitian}

Model penelitian dapat digambarkan sebagai berikut:

Variabel Independen (x) Variabel Dependen (y)

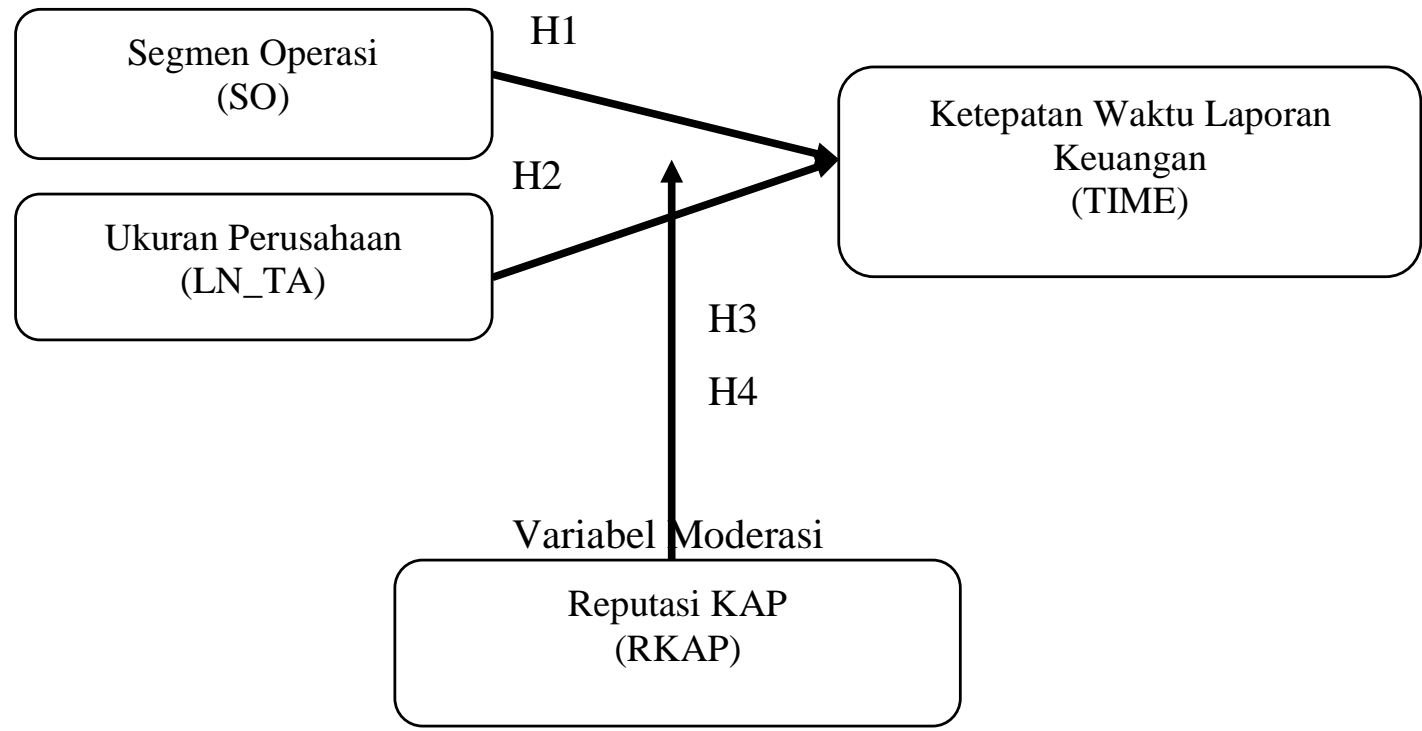

\section{Model Regresi}

Model regresi logistik yang digunakan untuk menguji hipotesis adalah sebagai berikut:

$$
\begin{gathered}
\text { TIME }=\beta 0+\beta 1 . S O+\beta_{2} \text { LN_TA }+ \\
\beta 3 . \text { RKAP }+\beta 4 . S O * \text { RKAP }+ \\
\text { B5.LN_TA*RKAP }+ \text { e }
\end{gathered}
$$

Keterangan :

TIME : Dummy variabel ketepatan waktu pelaporan laporan keuangan

SO $\quad$ : Jumlah Segmen Operasi

LN_TA : Ukuran Perusahaan (Size)

RKAP : Reputasi KAP (Kantor

Akuntan Publik)

e : Error

\section{HASIL DAN PEMBAHASAN}

\section{Statistik Deskriptif}

Objek penelitian merupakan LQ45 yang terdaftar di Bursa Efek Indonesia tahun 2015 2019. Berdasarkan kriteria dalam pemilihan sampel, maka sampel yang digunakan dalam penelitian ini sebanyak 26 perusahaan atau dengan 130 sampel.

Analisis statistik deskriptif digunakan untuk menjelaskan karakteristik sampel terutama mencakup nilai minimum, nilai maksimum dan nilai rata-rata (mean), dan standar deviasi. Berdasarkan data olahan menggunakan SPSS diperoleh hasil sebagai berikut:

Tabel 1. Statistik Deskriptif

\begin{tabular}{lrrrrr}
\hline Keterangan & $\begin{array}{c}\text { Total } \\
\text { Sampel }\end{array}$ & Minimum & Maximum & Mean & $\begin{array}{c}\text { Standart } \\
\text { Deviation }\end{array}$ \\
\hline SO & 130 & 2 & 9 & 4.28 & 1.67 \\
LN_TA & 130 & 28.99 & 34.89 & 31.78 & 1.50 \\
RKAP & 130 & 0 & 1 & .85 & .36 \\
TIME & 130 & 0 & 1 & .97 & .17 \\
\hline \multicolumn{2}{l}{} \\
\hline
\end{tabular}

Sumber: Data diolah 
Nilai minimum variabel jumlah segmen operasi (SO) adalah 2 segmen operasi dalam waktu 5 tahun sebanyak 17 sampel. Salah satunya perusahaan PT Bank Tabungan Negara Tbk pada tahun 2019 memiliki 2 segmen operasi perusahaan yaitu segmen konvensional dan segmen syariah. Nilai maksimum jumlah segmen operasi adalah 9 segmen, sebanyak 4 sampel. Salah satunya perusahaan PT Bank Mandiri Tbk pada tahun 2017 memiliki 9 segmen operasi yaitu segmen Wholesale (korporasi dan komersial), Kelembagaan, Retail (termasuk Wealth), Treasury, Kantor Pusat, Entitas Anak Syariah, Entitas Anak Asuransi dan Entitas Anak Lainnya. Sedangkan, rata-rata variabel segmen operasi adalah 4.28 dengan standar deviasi sebesar 1.67 .

Variabel ukuran perusahaan (LN_TA) memiliki nilai minimum sebesar 28.99 yaitu pada perusahaan PT Matahari Departemen Store Tbk pada tahun 2015. Sedangkan nilai maksimal sebesar 34.89 yaitu pada perusahaan PT Bank Rakyat Indonesia Tbk pada tahun 2019. Nilai rata-rata ukuran perusahaan sebesar 31.78 dengan standar deviasi 1.50.

Variabel Ketepatan waktu pelaporan dan segmen operasi menggunakan skala pengukuran dummy, sehingga data hanya 0 dan 1. Ketepatan waktu (TIME) memiliki rata-rata sebesar 0.97, yang berarti mendekati angka 1 sehingga dalam penelitan ini hampir semua perusahaan tepat waktu dalam melaporkan laporan keuangannya.

Kemudian, untuk reputasi KAP (RKAP) menggunakan skala pengukuran dummy, sehingga data yang digunakan hanya 0 dan 1. Variabel RKAP memiliki rata-rata sebesar 0.85 yang berarti 0.85 mendekati angka 1 sehingga sampel yang digunakan dalam penelitian ini hampir semua menggunakan KAP Big4 dalam mengaudit laporan keuangan perusahaan.

\section{Uji Kelayakan Model Regresi}

Pengujian kelayakan model regresi logistik dilakukan dengan menggunakan Goodness of Fit test yang diukur dengan nilai Chi-Square pada bagian bawah uji Hosmer and Lemeshow.
Tabel 2. Hosmer and Lemeshow Test

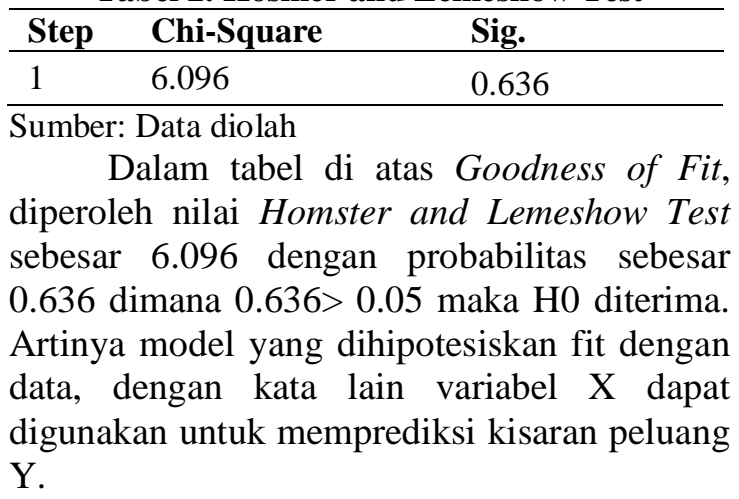

Uji Keseluruhan Model (Overall Model Fit)

Langkah selanjutnya adalah menguji keseluruhan model regresi (overall model fit). Pengujian dilakukan dengan membandingkan nilai antara -2 Log Likelihood (-2LL) pada awal (Block Number $=0$ ) dengan nilai -2 Log Likelihood (-2LL) pada akhir (Block Number = 1). Uji Overall Model Fit dapat dilihat di tabel sebagai berikut:

Tabel 3. Uji Overall Model Fit

\begin{tabular}{cc}
\hline Literation & $\mathbf{- 2}$ Log Likehood \\
\hline Step 0 & 35.726 \\
Step 1 & 35.660
\end{tabular}

Sumber: Data diolah

Uji kelayakan dengan memperhatikan angka pada awal -2 Log Likelihood block number = 0 , sebesar 35.726 dan angka pada -2 Log Likelihood block number $=1$, sebesar 35.660 . Dari model tersebut, menunjukan terjadinya penurunan nilai -2 Log Likelihood block number $=0$ dan -2 Log Likelihood block number $=1$ sebesar $35.726-35.660=0.066$. Penurunan tersebut menunjukan adanya model regresi yang lebih baik atau dengan kata lain model dihipotesiskan fit dengan data.

\section{Uji Nilai Cox \& Snell's R Square Negelkerke's $R$ Square}

Uji Cox \& Snell's R Square Negelkerke's $R$ Square digunakan untuk menilai seberapa variabel dependen dapat dijelaskan oleh variabel independent. Uji Cox \& Snell's $R$ Square Negelkerke's $R$ Square dapat dilihat pada tabel di bawah ini:

Tabel 4. Cox \& Snell's R Square Negelkerke's R Square

\begin{tabular}{ccc}
\hline Step & $\begin{array}{c}\text { Cox \& Snell } R \\
\text { Square Negelkerke }\end{array}$ & Negelkerke R Square \\
\hline 1 & 0.001 & 0.002 \\
\hline
\end{tabular}

Sumber: Data diolah 
Tabel di atas menunjukan nilai Cox \& Snell's $R$ Square sebesar 0.001 yang berarti memiliki nilai kurang dari $1 . \quad$ Nilai Negelkerke's $R$ Square sebesar 0.002 yang artinya variabel ketepatan waktu laporan keuangan dapat dijelaskan oleh jumlah segmen operasi dan ukuran perusahaan hanya sebesar $0.2 \%$ dan sisanya sebesar $99.8 \%$ dijelaskan oleh variabel-variabel lain diluar model penelitian.

\section{Uji Koefisiensi Regresi}

Pengujian koefisien regresi dilakukan untuk menguji seberapa jauh semua variabel bebas yang dimasukan dalam model mempunyai pengaruh terhadap variabel terikat. Uji koefisien regresi dapat dilihat di tabel 5. Uji Koefisien Regresi dengan menunjukan hasil pengujian dengan regresi logistik pada tingkat signifikansi 0,05.

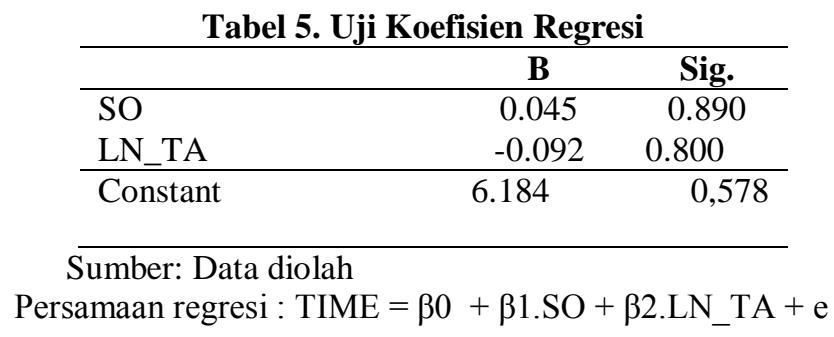

Pengujian Hipotesis 1 (Ha 1) Jumlah segmen operasi perusahaan berpengaruh terhadap ketepatan waktu pelaporan laporan keuangan. Variabel Segmen operasi menunjukan nilai koefisiensi regresi sebesar 0.045 dengan signifikansi sebesar 0.890, dimana $0.890>$ signifikansi 0.05 . Hal tersebut mengakibatkan Ha 1 tidak didukung, dengan demikian tidak terbukti bahwa jumlah segmen operasi berpengaruh terhadap ketepatan waktu laporan keuangan.

Pengujian Hipotesis 2 (Ha 2) Ukuran perusahaan berpengaruh terhadap ketepatan waktu pelaporan laporan keuangan. Variabel ukuran perusahaan menunjukan nilai koefisiensi regresi sebesar -0.092 dengan signifikansi sebesar 0.800 , dimana $0.800>$ signifikansi 0.05 . Hal tersebut mengakibatkan Ha 2 tidak didukung, dengan demikian tidak terbukti bahwa ukuran perusahaan berpengaruh terhadap ketepatan waktu pelaporan laporan keuangan.

Uji Interaksi Variabel Moderasi. Analisis koefisien moderating digunakan untuk menguji seberapa jauh variabel reputasi KAP mempengaruhi pengaruh antara jumlah segmen operasi dan ukuran perusahaan dengan ketepatan waktu pelaporan laporan keuangan.

Pengujian Interaksi Variabel Moderasi Untuk Hipotesis 3 (Ha 3)

Tabel 6. Koefisiensi Moderating 1

\begin{tabular}{llc}
\hline & \multicolumn{1}{c}{ B } & Sig. \\
\hline SO & 4.740 & 0.998 \\
SOxRKAP & -4.757 & 0.998 \\
Constant & 3.885 & 0,720
\end{tabular}

Sumber: Data diolah

Persamaan Regresi Ha 3: TIME $=\beta 0+\beta 1 . \mathrm{SO}+\beta \mathrm{LN} \_\mathrm{TA}+\beta 3 . \mathrm{RKAP}+\beta 4 \mathrm{SO} * \mathrm{RKAP}+\mathrm{e}$

Variabel SOxRKAP menunjukan nilai koefisiensi regresi sebesar -4.757 dengan signifikansi sebesar 0.998, dimana 0.998 > signifikansi 0.05 . Hal tersebut mengakibatkan Ha 3 tidak didukung, dengan demikian tidak terbukti bahwa Reputasi KAP mampu memoderasi pengaruh jumlah segmen operasi terhadap ketepatan waktu pelaporan laporan keuangan. 
Pengujian Interaksi Variabel Moderasi Untuk Hipotesis 4 (Ha 4)

Tabel 7. Koefisiensi Moderating 2

\begin{tabular}{lcc}
\hline & B & Sig. \\
\hline LN_TA & -0.558 & 0.998 \\
LN_TAxRKAP & -0.575 & 0.998 \\
\hline Constant & 3.885 & 0,720
\end{tabular}

Sumber: Data diolah

Persamaan Regresi Ha 4: TIME $=\beta 0+\beta 1 . \mathrm{SO}+$ $\beta 2 . \mathrm{LN} \_\mathrm{TA}+\beta 3 . \mathrm{RKAP}+\beta 4 \mathrm{LN} \_\mathrm{TA} * \mathrm{RKAP}+\mathrm{e}$

Variabel LN_TAxRKAP menunjukan nilai koefisiensi regresi sebesar -0.558 dengan signifikansi sebesar 0.998, dimana 0.998 > signifikansi 0.05. Hal tersebut mengakibatkan Ha 4 tidak didukung, dengan demikian tidak terbukti bahwa Reputasi KAP mampu memoderasi pengaruh ukuran perusahaan terhadap ketepatan waktu pelaporan laporan keuangan.

\section{HASIL DAN PEMBAHASAN}

Berdasarkan hasil penelitian diatas, penulis menemukan bukti empiris bahwa perusahaan - perusahaan LQ45 yang terdaftar di Bursa Efek Indonesia (BEI) masih terdapat adanya perusahaan yang tidak tepat waktu dalam menyampaikan laporan keuangan yang telah diaudit. Dalam penelitian yang dilakukan selama 5 tahun, perusahaan yang tepat waktu dalam menyampaikan laporan keuangan yang telah diaudit sebanyak 130 sampel, sedangkan sisanya sebanyak 4 sampel tidak tepat waktu menyampaikan laporan keuangan yang telah diaudit. Ketepatan waktu pelaporan sangat diperlukan perusahaan dalam menyampaikan laporan keuangan terutama yang telah diaudit. Laporan keuangan tersebut mengandung informasi yang relevan untuk memenuhi kebutuhan pengguna dalam proses pengambilan keputusan jika terdapat penundaan yang tidak semestinya, maka informasi yang dihasilkan akan kehilangan relevansinya. Dalam peraturan BAPEPAM Nomor: KEP-346/BL/2011 tentang Penyampaian Laporan Keuangan Berkala Emiten atau Perusahaan Publik mewajibkan semua perusahaan yang tercatat sahamnya di BEI harus menyampaikan laporan keuangan tahunan dan disertai dengan laporan akuntan dengan pendapat yang lazim dan disampaikan kepada Bapepam selambat-lambatnya pada akhir bulan ketiga (90 hari) setelah tanggal laporan keuangan tahunan. Oleh karena itu, perusahaan harus menaati peraturan yang telah dikeluarkan oleh BAPEPAM. Penulis mencoba menganalisis faktor-faktor yang dapat mempengaruhi ketepatan waktu laporan keuangan. Faktor yang diduga mempengaruhi ketepatan waktu pelaporan laporan keuangan adalah segmen operasi, ukuran perusahaan dan adanya reputasi KAP sebagai variabel moderasi. Setelah dilakukan pengujian hipotesis, diperoleh hasil sebagai berikut:

Hasil pengujian regresi logistik menunjukan bahwa variabel jumlah segmen operasi tidak berpengaruh terhadap ketepatan waktu pelaporan laporan keuangan. Jumlah segmen operasi perusahaan menggambarkan sumber audit dalam suatu perusahaan, sehingga apabila semakin banyak jumlah segmen perusahaan maka semakin lama waktu yang akan digunakan auditor dalam mengaudit laporan (Putra, 2016). Namun, hipotesis tersebut tidak mendukung pengaruh jumlah segmen operasi terhadap ketepatan waktu laporan keuangan. Perusahaan umumnya sudah mengantisipasinya melakukan audit terlebih dahulu terhadap segmen usaha, sehingga ini bukan menjadi hal yang mengakibatkan audit report lag (Putra, 2016).

Ukuran perusahaan tidak berpengaruh terhadap ketepatan waktu pelaporan laporan keuangan dengan nilai signifikansi 0.800 lebih besar dari nilai signifikansi 0.005 . Perusahaan tetap mempunyai tanggungjawab yang sama yaitu harus menyampaikan laporan keuangannya dengan tepat waktu. Hasil penelitian ini konsisten dengan Aquarista (2013) yang menunjukkan variabel ukuran perusahaan tidak berpengaruh terhadap audit delay karena auditor menganggap bahwa dalam proses pengauditan berapapun jumlah aset yang dimiliki oleh perusahaan akan diperiksa dengan cara yang sama, sesuai prosedur dalam standar profesional akuntan publik (Putri, 2015). Penelitian ini mendukung penelitian Melia (2012) bahwa ukuran perusahaan tidak 
berpengaruh terhadap ketepatan waktu pelaporan keuangan. Hal ini dikarenakan perusahaan yang tepat waktu maupun yang tidak tepat waktu dalam menyampaikan laporan keuangannya tidak mempertimbangkan karakteristik sebuah perusahaan. Perusahaan besar maupun perusahaan kecil sama-sama ingin menyampaikan laporan keuangan tepat waktu.

Dalam hal ini perilaku investor tidak tepat jika memberikan tekanan pada perusahaan besar saja. Perusahaan besar cenderung mendapat pengawasan lebih besar dari investor, regulator, dan sorotan masyarakat dibanding perusahaan kecil, sehingga perusahaan besar lebih berhati-hati dalam melaporkan keuangannya. Hal ini menyebabkan perusahaan besar tidak selalu tepat waktu dalam melaporkan keuangannya.

Hasil penelitian, Reputasi KAP memiliki nilai signifikansi $0.998>$ dari nilai signifikansi 0.05. artinya reputasi KAP tidak memoderasi pengaruh jumlah segmen operasi perusahaan terhadap ketepatan waktu pelaporan laporan keuangan. Kompleksitas operasi perusahaan merupakan salah satu karakteristik perusahaan yang dapat meningkatkan suatu tantangan pada audit dan akuntansi. Organisasi dengan banyak jenis atau jumlah pekerjaan dan unit menimbulkan masalah manajerial dan organisasi yang lebih rumit karena terjadi ketergantungan yang semakin kompleks. Namun, dari penelitian ini diperoleh hasil bahwa semakin banyak jumlah segmen operasi perusahaan dan perusahaan tersebut memiliki KAP yang berafiliasi dengan BIG4 tidak mempengaruhi ketepatan waktu pelaporan laporan keuangan.

Hasil penelitian, Reputasi KAP memiliki nilai signifikansi $0.998>$ dari nilai signifikansi 0.05. artinya reputasi KAP tidak memoderasi pengaruh ukuran perusahaan terhadap ketepatan waktu pelaporan laporan keuangan. Dyer dan McHugh (1975) dalam Sugita (2017) menyatakan bahwa manajemen perusahaan yang berskala besar cenderung diberikan insentif untuk mengurangi waktu audit dikarenakan perusahaan-perusahaan tersebut diawasi secara ketat oleh investor, pengawal permodalan dan pemerintah. Perusahaan yang memiliki ukuran perusahaan yang besar dan menjadi klien dari KAP Big4 akan mampu mempercepat proses audit laporan keuangan perusahaan tersebut. Hal ini dikarenakan KAP besar yang berafiliasi Big four akan dapat menyelesaikan pekerjaan audit dengan lebih efektif, karena KAP Big Four pada umumnya memiliki sumber daya yang lebih besar (kompetensi, keahlian, dan kemampuan auditor, fasilitas, sistem dan prosedur pengauditan yang digunakan, dll) dibandingkan dengan KAP non Big four (Prabandari dan Rustiana, 2007) dalam Sugita (2017). Namun dari hasil penelitian ini, Reputasi KAP tidak memoderasi pengaruh ukuran perusahaan terhadap ketepatan waktu pelaporan laporan keuangan, sehingga sebesar apapun ukuran perusahaan dan perusahaan menggunakan KAP yang berafiliasi dengan BIG4 tidak mempengaruhi ketepatan waktu pelaporan laporan keuangan perusahaan. Selain itu dalam penelitian ini sebanyak 110 sampel dari 130 sampel menggunakan KAP Big 4 dalam menyelesaikan laporan auditnya, sehingga akan semakin cepat dalam penyelesaian laporan auditnya.

\section{SIMPULAN}

Berdasarkan penelitian ini, maka penulis dapat menyimpulkan sebagai berikut:

1. Jumlah segmen operasi perusahaan dan ukuran perusahaan tidak berpengaruh terhadap ketepatan waktu pelaporan laporan keuangan pada perusahaan LQ45 yang tercatat di Bursa Efek Indonesia (BEI) periode tahun 2015 - 2019

2. Reputasi KAP tidak memoderasi pengaruh jumlah segmen operasi perusahaan dan ukuran perusahaan terhadap ketepatan waktu pelaporan laporan keuangan pada perusahaan LQ45 yang tercatat di Bursa Efek Indonesia (BEI) periode tahun 2015 2019

\section{SARAN}

Implikasi kebijakan direkomendasikan untuk pihak-pihak yang berhubungan dengan ketepatan waktu pelaporan laporan keuangan perusahaan, adapun saran yang dibuat penulis adalah sebagai berikut:

Perusahaan perlu mempertahankan ketepatan waktu laporan keuangan, perusahaan dapat menaati peraturan yang telah ditetapkan oleh BAPEPAM atau OJK (tahun 2018). Hal ini tentu dapat menjadi pertimbangan investor dalam keputusan investasi. Perusahaan yang belum tepat waktu juga harus meningkatkan 
kualitas manajemen dan KAP agar laporan keuangan dan laporan audit dapat terselesaikan secara tepat waktu sehingga perusahaan tidak kehilangan relevansi informasi laporan keuangan. Ketepatan waktu pelaporan laporan keuangan memberikan keuntungan bagi masyarakat dan investor karena dapat menggunakan laporan keuangan sebagai dasar pengambilan keputusan.

\section{REFERENSI}

Ariyani, Ni Nyoman T.D, dan I Ketut Bidhiarta. (2014). Pengaruh Profitabilitas, Ukuran Perusahaan, Kompleksitas Operasi Perusahaan dan Reputasi KAP Terhadap Audit Report Lag Pada Perusahaan Manufaktur. E-Jurnal Akuntansi Univesitas Udayana, 8 (2).

Aquarista, Muh Rizal. 2013. Analisis FaktorFaktor yang Mempengaruhi Audit Delay pada Perusahaan yang Terdaftar dalam indeks LQ45 di Bursa Efek Saham”. Universitas Airlangga.

Barkah, Gustinas dan Hadi Pramono. (2016). Pengaruh Ukuran Perusahaan, Profitabilitas, dan Solvabilitas terhadap Audit Delay pada Perusahaan Manufaktur yang Terdaftar di BEI Periode 2010-2012. Kompartemen, 14(1).

Ikatan Akuntansi Indonesia. 2015. Standar Akuntansi Keuangan. Jakarta: Salemba Empat.

Jensen, M. and W. Meckling. (2005). Theory of The Firm: Managerial Behavior, Agency Costs. Journal of Financial Economics, 3, 305-360.

Melia, Riris, 2012, Faktor-Faktor Yang Mempengaruhi Ketepatan Waktu Penyampaian Laporan Keuangan pada Perusahaan Manufaktur yang Masuk dalam Daftar Efek Syariah (DES) Priode 2008-2010), Fakultas Stariah Dan Hukum Universitas Islam Negeri Sunan Kalijaga, Yogyakarta

Murti, Ni Made Dwi dan Ni Luh Sari Widhiyani. (2016). Pengaruh Ukuran
Hasil yang tidak signifikan pada pengujian jumlah segmen operasi dan ukuran perusahaan berpengaruh terhadap ketepatan waktu laporan keuangan agar memberikan masukan bagi peneliti di masa datang untuk menggunakan variabel lain yang diduga mempengeruhi ketepatan waktu laporan keuangan.

Perusahaan dan Profitabilitas Pada Audit Delay Dengan Reputasi KAP Sebagai Variabel Pemoderasi. E-Jurnal Akuntansi Universitas Udayana, 16 (1).

Ningsih, I Gusti A.P.S dan Ni luh Sari Widhiyani. (2015). Pengaruh Ukuran Perusahaan, Laba Operasi, Solvabilitas, dan Komite Audit pada Audit Delay. EJurnal Akuntansi Universitas Udayana, 12(3), pp. 481-495

Putri, Apriliani Issana dan Bambang Suryono. (2015). Berbagai Faktor yang Mempengaruhi Ketepatan Waktu Pelaporan Keuangan”. Jurnal Ilmu dan Riset Akuntansi, 5(7).

Putra, Riensky Dewangga dan Majidah. (2016). Analisis Determinasi Audit Report Lag Studi pada Perusahaan Manufaktur Subsektor Industri Barang Konsumsi yang tercatat DI BEI Periode 2010-2014. E-Proceeding of Management, 3(3).

Sugita, Krismayanti. (2017). Ukuran KAP Memoderasi Pengaruh Financial Distress dan Ukuran Perusahaan Klien pada Audit Report Lag. E-Journal Akuntansi: Universitas Udayana, 21(1).

Supriyati, Rolinda, Yuliasri. (2007). Faktorfaktor yang Mempengaruhi Audit Delay. Fokus Ekonomi, 10 (Nomor 3.

Undang-undang No. 28 Tahun 1995 tentang Peraturan Pasar Modal

Undang-Undang Nomor KEP-346/BL/2011 tentang Penyampaian Laporan Keuangan Berkala Emiten atau Perusahaan Publik. 
Undang-undang RI No. 20 Tahun 2008 tentang Usaha Mikro, Kecil, dan Menengah. 
JRAK, Volume 17, No.1 Februari 2021 